\title{
Distribution of selenium binding proteins in liver from two species of penguins from Bouvetøya ${ }^{1}$
}

\author{
G. NORHEIM, F. MEHLUM, C. BECH and M. T. MOKSNES
}

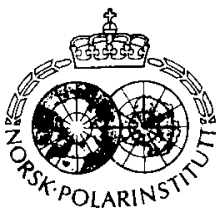

Norheim, G., Mehlum, F., Bech, C. \& Moksnes, M.T, 1991: Distribution of selenium binding proteins in
liver from two species of penguins from Bouvetøya. Polar Research $9(1), 109-111$.
Chinstrap penguin Pygoscelis antarctica and macaroni penguin Eudyptes chrysolophus were collected at
Bouvetøya in the south Atlantic. The average hepatic selenium levels for the two species were $6.6 \pm 2.9$
and $23.6 \pm 3.4 \mu \mathrm{g} / \mathrm{g}$ wet weight $(\mathrm{P}<0.001)$, respectively. The total hepatic glutathione peroxidase $(\mathrm{GSH}-$
$\mathrm{Px}$ ) activity in the two species was $629 \pm 58$ and $838 \pm 88 \mu \mathrm{kat} / \mathrm{kg}(\mathrm{P}<0.001)$, respectively. The average
selenium dependent GSH-Px activity was $96 \pm 3.2 \%$ of the total activity. All selenium was present in the
cytosol. The selenium binding compounds were separated on Sephadex G-75 into three fractions, a high
molecular weight fraction, a metallothionein fraction, and a third non-protein selenium containing fraction.
There seems to be an agreement between the amount of selenium recovered in the first fraction and the
GSH-Px activity. In chinstrap and macaroni penguins, the percentage of hepatic selenium recovered in the
third non-protein fraction was $83 \pm 2.6$ and $94 \pm 1.1 \%$ (P $<0.001)$, respectively.

Gunnar Norheim ${ }^{2}$, Department of Pharmacology and Toxicology, National Veterinary Institute, P.O. Box 8146 Dep, 0033 Oslo 1, Norway; Fridtjof Mehlum, Norsk Polarinstitutt, P.O. Box 158, N-1330 Oslo Lufthaun, Norway; Claus Bech, Department of Zoology, University of Trondheim, N-7055 Dragvoll, Norway; Milica T. Moksnes, Department of Fish Diseases and Aquiculture, National Veterinary Institute, P.O. Box 8156 Dep, N-0033 Oslo 1, Norway.

Selenium is an essential trace element and in many animal species and in humans the hepatic level of this element gives an estimate of the nutritional status. At the same time selenium is a toxic element and there seems to be an optimum intake (Moksnes \& Norheim 1983). However, in some animal species with very high levels of selenium in the liver, there is no relationship with the intake. On the other hand, the selenium level may be related to the level of some heavy metals, especially mercury (Kari \& Kauranen 1978; Norheim et al. 1984; Norheim 1987).

Selenium functions as an integrated part of the enzyme glutathione peroxidase (GSH-Px) and it is assumed that this is its most important role. However, selenium may also have other functions in the body (Magos \& Webb 1980).

Little is known about how selenium is bound in animals with high hepatic levels, but it is assumed that it is involved in the detoxification of heavy metals such as mercury and cadmium. The aim of the present study was to make a preliminary investigation of the selenium binding components in species of birds with naturally high hepatic levels of selenium. To this end we have studied two species of penguins.

\footnotetext{
'Publication No. 101 of the Norwegian Antarctic Research Expeditions (1984/85)

${ }^{2}$ Deceased January 9, 1991
}

\section{Materials and methods}

\section{Sampling}

During the Norwegian Antarctic Research Expedition 1984/ 85, specimens of chinstrap Pygoscelis antarctica and macaroni penguin Eudyptes chrysolophus were collected at Bouvetøya $\left(54^{\circ} 26^{\prime} \mathrm{S}, 3^{\circ} 21^{\prime} \mathrm{E}\right)$ in the south Atlantic. The birds were chloroformed, and samples of liver were removed and stored in liquid nitrogen.

\section{Analytical methods}

Selenium was determined by a hydride generator-atomic absorption method after digestion in a mixture of perchloric and nitric acid (Norheim \& Haugen 1986).

The glutathione peroxidase (GSH-Px) activity in liver was measured at $37^{\circ} \mathrm{C}$ after homogenization in $0.15 \mathrm{~mol} / \mathrm{l}$ of potassium chloride (Paglia \& Vatentine 1967; Moksnes \& Norheim 1983). The total GSH-Px activity was measured with cumene hydroperoxide as substrate (Prohaska \& Ganther 1977), while the selenium dependent GSH-Px activity was measured with hydrogen peroxide as substrate.

The gel filtration was carried out at $4^{\circ} \mathrm{C}$ on a Sephadex G-75 superfine (Pharmacia) column $(2.6 \times 40 \mathrm{~cm})$. The ascending flow rate was $12.5 \mathrm{ml} / \mathrm{h}$ and $5 \mathrm{ml}$ fractions were collected. One part of the liver sample was homogenized in two parts of a 
Table 1. Mean hepatic concentrations and ranges of selenium $(\mu \mathrm{g} / \mathrm{g}$ wet weight), total and selenium dependent GSH-Px ( $\mu \mathrm{kat}$ / $\mathrm{kg}$ wet weight) in chinstrap $P_{\text {ygoscelis antarctica }}$ and macaroni penguin Eudyptes chrysolophus from Bouverøya.

\begin{tabular}{lll}
\hline & $\begin{array}{c}\text { Chinstrap } \\
\text { penguin }\end{array}$ & $\begin{array}{c}\text { Macaroni } \\
\text { penguin }\end{array}$ \\
\hline$\mu \mathrm{g} \mathrm{Se} / \mathrm{g}$ & $6.6 \pm 2.9$ & $23.6 \pm 3.4$ \\
$\mathrm{n}=10$ & $(4.7-11.4)$ & $(19.7-28.2)$ \\
$\mu \mathrm{kat}$ GSH-Px/kg & $629 \pm 58$ & $838 \pm 88$ \\
$\mathrm{n}=4$ & $(577-711)$ & $(723-929)$ \\
Cumene hydroperoxide & & \\
$\begin{array}{l}\mu \mathrm{kat} \text { GSH-Px/kg } \\
\mathrm{n}=4\end{array}$ & $603 \pm 54$ & $802 \pm 91$ \\
Hydrogen peroxide & $(561-677)$ & $(722-923)$ \\
\hline
\end{tabular}

$0.01 \mathrm{~N}$ Tris buffer ( $\mathrm{pH}=8.0$ at $4^{\circ} \mathrm{C}$ ) as described prcviously (Norheim \& Steinnes 1975; Norheim \& Søli 1977).

Students t-test. with a significance level of 0.05 , was used for testing differences between means.

\section{Results}

The results of the analysis are given in Table 1. The average selenium levels in the liver of 10 chinstrap and 10 macaroni penguins were $6.6 \pm 2.9$ and $23.6 \pm 3.4 \mu \mathrm{g} / \mathrm{g}$ wet weight $(\mathrm{P}<0.001)$. respectively. In four chinstrap penguins, the average hepatic GSH-Px activity was $629 \pm 58 \mu \mathrm{kat} / \mathrm{kg}$ wet wcight using cumenc hydroperoxide as substrate and $603 \pm 54 \mu \mathrm{kat} / \mathrm{kg}$ using hydrogen peroxide as substrate. The corresponding GSHPx activities in four macaroni penguins were $838 \pm 88$ and $802 \pm 91 \mu \mathrm{kat} / \mathrm{kg}$. respectively. The difference in enzyme activity between the two species was statistically significant

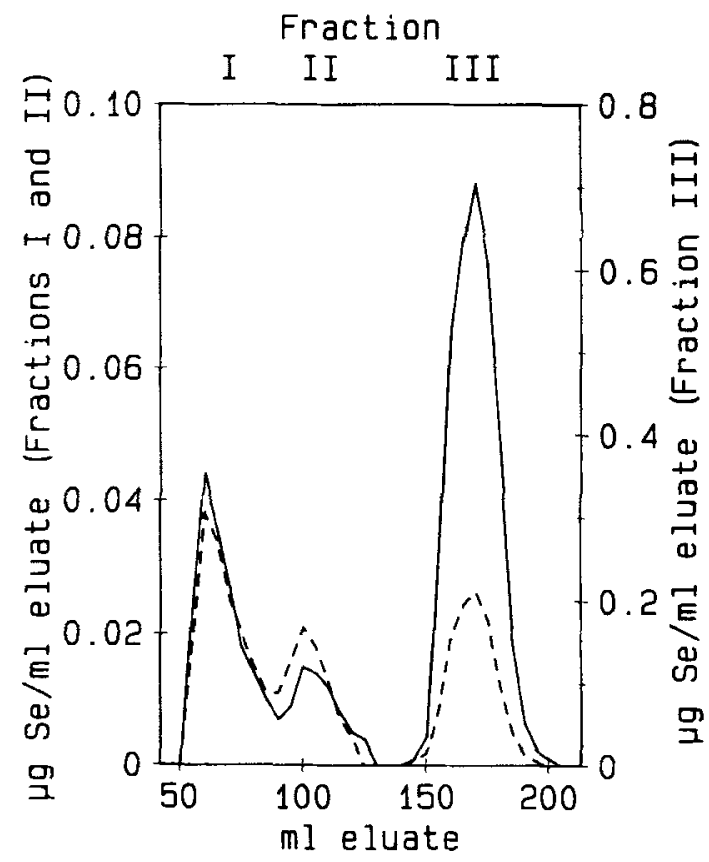

Fig. I. The distribution of soluble hepatic selenium binding compounds in a chinstrap penguin $(6.1 \mu \mathrm{g} \mathrm{Se} / \mathrm{g}$ liver wet weight, dashed line ) and a macaroni penguin $(19.7 \mu \mathrm{g} / \mathrm{g}$, solid line) after gel filtration on Sephadex G-75.

$(\mathrm{P}<0.01)$. On an average, the selenium dependent activity measured with hydrogen peroxide as substrate was $96 \pm 3.2 \%$ $(n=8)$ of the total GSH-Px activity measured with cumene hydroperoxide as substrate. There was no difference between the two species with respect to this percentage.

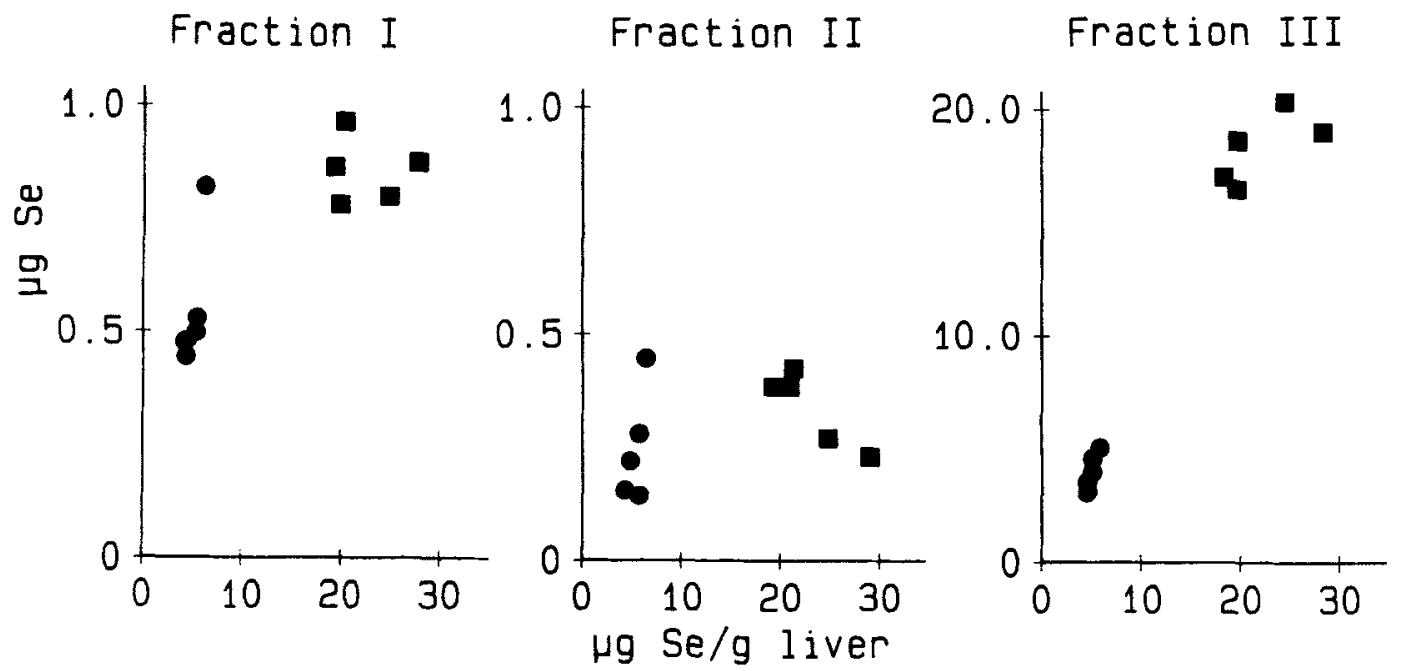

Fig. 2. The amount of selenium in Fractions I. II, and III as a function of the hepatic selenium concentration in chinstrap (๑) and macaroni ( $\mathbf{E})$ penguins. 
The average recovery of selenium present in the liver extracted with Tris buffer for five chinstrap and five macaroni penguins was $100 \pm 7.8 \%(n=10)$. All of the selenium was also recovered after the gel filtration. The selenium binding compounds present in the cytosol were separated into three main fractions on the Sephadex G-75 column (Fig. 1). Fraction II seemed to coincide with metallothionein. Fraction III, which was eluted near the total volume of the column, contained non-protein selenium containing compounds. The amounts of selenium present in Fractions I, II, and III are shown as a function of the liver concentration in Fig. 2. The difference in selenium amount in Fractions I and III between chinstrap and macaroni penguins is statistically significant $(P<0.01$ and $P<0.001$, respectively), while there is no difference in Fraction II.

\section{Discussion}

The hepatic levels of selenium in chinstrap and macaroni penguins found in the present investigation correspond with earlier findings (Norheim 1987). Thus, it is assumed that these levels are representative of the population of the two penguin species at Bouvetøya. It has previously been shown that the selenium concentration may be related to the levels of heavy metals such as cadmium and mercury (Norheim 1987) rather than being representative of the nutritional status.

Studies of GSH-Px in birds which bear relevance to the present study are rare. However, the GSH-Px activities observed seem to be within reasonable limits. If we calculate the amount of selenium present in liver and recovered in Fraction I, the figures for chinstrap and macaroni penguins are $0.64 \pm 0.11$ and $0.99 \pm 0.17 \mu \mathrm{g} \mathrm{Se} / \mathrm{g}$ liver wet weight, respectively. In an experimental study, chickens with a hepatic selenium level of $0.40-0.45 \mu \mathrm{g} / \mathrm{g}$ had a hepatic GSH-Px activity of 285-340 $\mu \mathrm{kat} /$ $\mathrm{kg}$, both on a wet weight basis (Norheim \& Moksnes 1985; Moksnes \& Norheim 1986). Although the ratio between the amount of selenium bound to GSH-Px and other selenium proteins, that may be present in Fraction I, is not known either in chickens or in penguins, the present results seem to be in agreement with the experimental results. However, the amount of data up till now is very limited. Practically all of the GSHPx activity recorded was present as selenium dependent activity. In chickens and ducks the selenium dependent activity was about $80 \%$. This percentage was lower in selenium-depleted birds (Schafer et al. 1982; Xu \& Diplock 1983; Norheim \& Moksnes 1985).

All hepatic selenium seems to be present in the cytosol, but the main part is not bound to proteins. In chinstrap and macaroni penguins, the percentages of hepatic selenium recovered in Fraction III were $83 \pm 2.6$ and $94 \pm 1.1$ ( $\mathrm{P}<0.001)$, respectively. The distribution of the selenium binding components had some resemblance to the distribution in human liver except for the much lower share of non-protein selenium in this species (Norheim \& Steinnes 1976). A non-protein fraction seems also to be present in rats dosed both with mercury and selenium. However, in these experiments only $16 \%$ of the hepatic selenium was present in the soluble fraction (Komsta-Szumska \& Chmielnicka 1977). The first eluated peak in the penguin samples is broad and seems to include several selenium binding proteins. The second peak seems to coincide with metallothionein and contains a mean selenium concentration of $0.32 \pm 0.10 \mu \mathrm{g} / \mathrm{g}$ referring to liver weight, with no difference between the species.
Acknowledgement. - The technical assistance of Elisabet Mo $\emptyset k l a n d$ and Atle Haugen is greatly appreciated.

\section{References}

Kari, T. \& Kauranen, P. 1978: Mercury and selenium contents of seals from fresh and brackish waters of Finland. Bull. Environ. Contain. Toxicol. 56, 1297-1303.

Komsta-Szumska, E. \& Chmielnicka, J. 1977: Binding of mercury and selenium in subcellular fractions of rat liver and kidneys. Arch. Toxicol. 38, 217-228.

Magos, L. \& Webb, M. 1980: The interaction of selenium with cadmium and mercury. CRC Crit. Rev. Toxicol. 8, 1-42.

Moksnes, K. \& Norheim, G. 1983: Selenium and glutathione peroxidase levels in lambs receiving feed supplemented with sodium selenite or selenomethionine. Acta Vet. Scand. 24, 45-58.

Moksnes, K. \& Norheim, G. 1986: A comparison of selenomethionine and sodium selenite as a supplement in chicken feed. Acta Vet. Scand. 27, 103-119.

Norheim, G. 1987: Levels and interactions of heavy metals in sea birds from Svalbard and the Antarctic. Environ. Pollut. 47, 83-94.

Norheim, G. \& Haugen, A. 1986: Precise determination of selenium in tissues using automated wet digestion and an automated hydride generator-atomic absorption spectroscopy system. Acta Pharmacol. Toxicol. 59, Suppl. VII, 610612.

Norheim, G. \& Moksnes, K. 1985: Distribution and elimination of selenium and glutathione peroxidase (GSH-Px) in chickens after supplementation with sodium selenite or selenomethionine. Pp. 493-495 in Mills, C. F., Bremner, I. \& Chesters, J. K. (eds.): Trace elements in man and animals TEMA 5. Commonwealth Agricultural Bureaux, Slough, U.K.

Norheim, G. \& Steinnes, E. 1974: Determination of proteinbound trace elements in biological material by gel filtration and neutron activation analysis. Anal. Chem. 47, 1688-1690.

Norheim, G. \& Steinnes, E. 1976: Distribution of some proteinbound trace elements among soluble protein fractions from human liver. Acta Pharmacol. Toxicol. 38, 137-144.

Norheim, G. \& Søli, N. E. 1977: Chronic copper poisoning in sheep. II. The distribution of soluble copper-, and molybdenum-, and zinc-binding proteins from liver and kidney. Acta Pharmacol. Toxicol. 40, 178-187.

Norheim, G., Sivertsen, T., Brevik, E. M. \& Frøslie, A. 1984: Kvikksølv og selen i villmink (Mustela vison) fra Norge. Nord. Vet. Med. 36, 43-48.

Paglia, D. E. \& Valentine, W. N. 1967: Studies on the quantitative and qualitative characterization of erythrocyte glutathione peroxidase. J. Lab. Clin. Med. 70, 158-169.

Prohaska, J. R. \& Ganther, H. E. 1977: Glutathione peroxide activity of glutathione-S-transferases purified from rat liver. Biochem. Biophys. Res. Commun. 76, 437-445.

Schafer, K., Manner, K. \& Bronsch, K. 1982: Einfluss von Selenzulagen auf die Glutathion-Peroxidase Aktivitaten in Erythrozyten, Plasma und Leber bei Jung- und Legehennen. Zbl. Vet. Med. A. 29, 271-278.

Xu, G. L. \& Diplock, A. T. 1983: Glutathione peroxidase (EC 1.11.1.9), glutathione-S-transferase (EC 2.5.1.13), superoxide dismutase $(E C$ 1.15.1.13) and catalase $(E C$ 1.11.1.6) activities in tissues of ducklings deprived of vitamin $E$ and selenium. Brit. J. Nutr. 50, 437-444 
